\title{
Early Career Teachers’ Evolving Content-Area Literacy Practices
}

\author{
Anne Murray-Orr and Jennifer Mitton-Kukner
}

\section{St. Francis Xavier University}

\begin{abstract}
Becoming effective teachers is dependent upon a variety of factors intersecting with early career teachers' beginning teaching experiences. This paper provides a glimpse into ways in which four early career secondary school teachers began to embed literacies into their teaching practices in content areas and how their approaches shifted between the final term of their teacher education program in 2013 and their first year of teaching in 2014. The authors explore three factors that may shape the practices of early career teachers, with disciplinary specialties in science, math, social studies, and other content areas, as they persist in infusing their teaching practice with literacy strategies over the first year of teaching, or alternatively discontinue using these strategies. These factors are coursework in a Literacy in the Content Areas course during their teacher education program, teaching context, and disciplinary specialty.
\end{abstract}

Keywords: early-career teachers; secondary teachers; content-area literacy; disciplinary literacy; pedagogical content knowledge

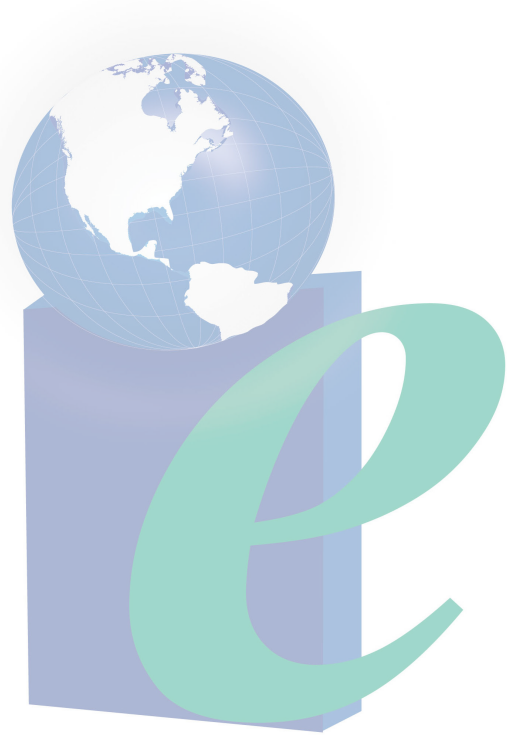




\section{Early Career Teachers’ Evolving Content-Area Literacy Practices}

The purpose of this paper is to explore how early-career secondary school teachers, with disciplinary specialties in science, math, social studies, and other content areas, persist in infusing their teaching practice with literacy strategies over the first year of teaching, or alternatively discontinue using these strategies. Integration of literacy practices, including traditional, visual, media, and digital literacies, is a feature of courses in the preservice curricula of many teacher education programs. Several Canadian studies have explored the effect of such programs on preservice teachers (Begoray, 2002, 2008; Rowsell, Kosnik, \& Beck, 2008), but few have followed them into their first years of teaching. We teach two sections of a Literacy in the Content Areas (LCA) course at a small, eastern Canadian university, and have noted how preservice teachers in various disciplines responded positively to the course. In 2012, we began to inquire into the experiences of these preservice teachers as they attempted to integrate literacy strategies into their practicum placements in the final term of their Bachelor of Education (BEd) programs. We have since begun to study the literacy practices of these teachers as they move into their initial years of teaching. In this paper, we discuss findings from the second and third years (2013 and 2014) of our multi-year longitudinal study, exploring the contrasts and similarities between first-year teachers' literacy integration in their practices during the final year of their teacher education programs and in their first year of teaching.

Becoming an effective teacher is not only a long and complex process (Flores \& Day, 2006; Cochran-Smith et al., 2012), but it is also dependent upon a variety of factors intersecting with an early career teacher's (ECT) beginning teaching experiences. Several well-documented factors that influence beginning teachers' experiences include the quality of an ECT's teacher education program (Issacs et al. 2007), the school context in which an ECT begins to teach (Day, Sammons, Qing, Kington, \& Stobart, 2007, 2009), the kinds of mentoring an ECT is able to access (Kemmis, Heikkinen, Fransson, Aspfors, \& Edward-Groves, 2014), and the induction programs that are available to an ECT (Patrick, Elliot, Hulme, \& McPhee, 2010). The first years of teaching compel new teachers to think about who they are in relation to their efficacy in the classroom, leading many new teachers to become entrenched in survival mode (Thomas \& Beauchamp, 2011). Cochran-Smith et al.(2012) found that "strong subject matter knowledge alone is not enough to produce strong teaching practice or enable teachers to stay at the same school or in teaching" and that more research is needed to determine what kinds of ECTs persevere in the profession (p. 875).

Mansfield, Beltman, and Price (2014), exploring how ECTs manage the challenges they encounter in their first years of teaching, note the importance of personal (i.e. family and friends) and contextual (i.e. school conditions) resources influencing their resilience. Some of what affects the development of new teachers is beyond the grasp of teacher education, particularly the emphasis placed upon personal structures and supports. However, Darling-Hammond (2006) claims that much can be done in teacher education programs to influence the development of capable new teachers despite the challenges associated with the process. In particular, DarlingHammond notes the importance of coursework interwoven with field experiences as enabling teacher candidates to progress from a self-focus to a student-focus. This concept has relevance for our study, as one of the areas we investigate is the impact of the LCA course on the BEd students we teach. 


\section{Early Career Content-Area Teachers' Inclusion of Literacy into Their Teaching Practices}

Because literacies are integral to students' career aspirations, approaches to learning, and quality of life (Street, 2014; UNESCO, 2008), there is a need to explore how early-career, content-area teachers use literacy practices to support the learning of children and youth in schools, as Alger (2009) exemplified. While there is a rich history of inquiry into ECTs' teaching practices and how they are shaped over time, from early research by Lortie (1975) and Fuller and Brown (1975) to more recent studies (Darling-Hammond, 2006; Flores \& Day, 2006; Cochran-Smith et al., 2012), less is known about new teachers' development in relation to teaching specific disciplines (Wood, Jilk, \& Paine, 2012). A number of researchers have begun the task of inquiring into the experiences of ECTs in particular disciplines, in order to elevate "the prominence of subject matter understanding and needs" (Wood et al., p. 1).

Our study focuses on whether and how this development includes increasing proficiency in integrating literacy practices in high school content-area courses. Shulman's (1986) notion of pedagogical content knowledge (PCK) provided a conceptual framework for us to explore how content-area teachers develop their abilities to infuse literacies into their teaching practices. Teachers with PCK have a deep understanding of the subject, curricular development, and how students learn concepts and topics particular to the subject. PCK is closely related to literacy in various content areas in terms of the importance of understanding which forms of representation are best suited to the teaching and learning of topics in one's subject area and what learners bring to the learning of new content. Shulman notes that pedagogical content knowledge grows organically over time as teachers acquire more depth and breadth in their practice.

\section{Differences Between Content-Area Literacy and Disciplinary Literacy}

Content-area literacy has recently come under scrutiny, as the importance of disciplinary literacy has been highlighted (Dunkerly-Bean \& Bean, 2016). Hynd-Shanahan (2013) makes clear the distinction between these two terms, writing that the difference is "in the aspect of literacy being emphasized" (p. 93). She notes that in classrooms using a content-area literacy approach, "students can develop a 'toolbox' of strategies that can be used no matter what the field to help them with [reading] comprehension" (Hynd-Shanahan, 2013, p. 93). In contrast, Hynd-Shanahan (2013) writes, in a disciplinary literacy approach, "the discipline itself and the ways of thinking in that discipline determine the kinds of strategies to use to understand texts" (p. 94). To further clarify the differences, Brozo, Moorman, Meyer, and Stewart (2013) describe the multipurpose strategies that are the hallmark of content-area literacy as an

outside-in approach in which generic strategies are pushed onto the process of disciplinary reading and learning ... [while] disciplinary literacy evolves from the inside out because the text itself and the goals for reading the text dictate the reading process. (p. 354)

\section{Resisting a Binary}

Brozo et al. (2013), Hynd-Shanahan (2013), and Dunkerly-Bean and Bean (2016) concur that despite the current emphasis on disciplinary literacy, both approaches to teaching literacies have value in content-area classrooms, and need not be seen in binary opposition. Dunkerly-Bean and Bean (2016) resist a dualistic view and combine the two terms to convincingly state, "The field 
of content-disciplinary literacy has brave and compelling work to do" (p. 470) in living up to their potential to support the learning of students.

It is our intention to also resist this binary as we focus on ECTs' teaching experiences in their particular disciplines and how they integrate literacy in their classrooms. We use the term content-area literacy because it reflects our education course title and focus and allows us to inquire into how ECTs in our study spoke of using "feasible and relevant contextual applications of generic content area literacy strategies" (Brozo et al., 2013, p. 355). We investigated ECTs' experiences with a literacy lens in order to tease out how they refine their practice, considering the following three areas: (a) each ECT's teaching area(s)/discipline(s), (b) what they carry forward from their LCA courses in teacher education programs, and (c) what they are learning about literacy and teaching/learning in school contexts.

\section{Research Design and Methodology}

In this paper, we draw on an ongoing multi-year, longitudinal study of over 60 preservice and early career teachers' use of content-area literacy strategies (Murray-Orr \& Mitton-Kukner, 2015; Mitton-Kukner \& Murray-Orr, 2015; Mitton-Kukner \& Murray-Orr, 2014; Murray-Orr, Mitton-Kukner, \& Timmons, 2014). We explore how four early career teachers' capacities for incorporating literacies into their teaching developed from their final term in a BEd ${ }^{1}$ program to the end of their first year of teaching. This research project has been granted ethics approval from St. Francis Xavier University's Research Ethics Board. Although 2014 was the third year of our study, it was the first year we followed preservice teacher participants into their first year of teaching. In 2012 and 2013, we focused on preservice teachers.

Using a single-case design with multiple units of analysis (Yin, 2014), we investigated how four early-career teachers refined and shifted their teaching practices related to the use of literacy strategies, as they made the transition from a BEd program to their first year of teaching in new locations in Canada. Yin (2014) describes how case study design includes "a set of cases with exemplary outcomes in relation to some evaluation question, such as 'how and why a particular intervention has been implemented smoothly"' (p. 62). In this study, we consider ECTs' participation in the LCA course we taught to be the "intervention." Yin (2014) notes that embedded cases with "contrasting situations" (p. 64) may also be chosen. Each unit of analysis (i.e. each ECT) has his/her own context and the units of analysis, taken together, provide findings that enable further theory development. Yin argues that findings are strengthened when contrasting multiple units of analysis are used, as this offers more possibility of theory refinement.

\section{Data Collection}

In the spring of 2014, we invited 10 first-year teachers, who were former preservice teachers in the BEd program at our small Eastern Canadian university and participants of this study in 2013, to do follow-up interviews about their experiences integrating literacy into their content area teaching. These teachers were first-year high school math, science, social studies, music, and physical education teachers. Of the 10 people invited, five, first-year teachers were able to take part and were interviewed between March and June 2014 by Skype and phone. Four of the five are the focus of this paper. The fifth participant interviewed was not included in this paper because this participant did not move to a new location in Canada, one of the factors we consider in this paper. A first interview was conducted with each ECT in April or May, 2013, as 
they completed their BEd program and a second interview in the spring of 2014, as they approached the end of their first year of teaching, for a total of eight interviews. The 2014 interviews could not be conducted face-to-face because they were teaching in locations far from the university from which they graduated.

Four ECT participants. The four ECTs whom we interviewed as participants in this study were first-year teachers working in a variety of contexts in western and northern Canada, after graduating from a BEd program in eastern Canada. The four ECTs included Bryon, a new science and math teacher teaching these subjects in Grade 9 in a private school for students with learning disabilities in an urban location in western Canada; Elizabeth, a Grades 7-10 physical education teacher in a medium-sized town in western Canada; Sandra, a social studies and physical education teacher of Grades 7-9 at a middle school in a small community in western Canada; and Don, a social studies and ELA teacher in Grades 7-9 in a small fly-in community in northern Canada.

\section{Analyzing the Data}

We began our data analysis by independently analyzing the interview transcripts (Creswell, 2007; Merriam, 2009) of the four ECTs. Each author looked for possible patterns emerging in the interview transcripts, creating numerous open codes. As part of this individual process, we then each started to cluster open codes that seemed related into a smaller number of analytic codes (Merriam, 2009). After completing this stage, we met several times to discuss the similarities amongst the analytic codes each of us had created. As we refined these codes, we returned to the interview transcripts to confirm where we had enough data to support their inclusion in the three factors that we eventually conceptualized as shaping the practices of ECTs with content-area specialties. These three factors are the impact of course activities and assignments in the LCA course during the teacher education program, teaching context, and disciplinary specialty.

We plan to continue this study, adding more participants each year and following these participants over their first three years of teaching. We anticipate that as the study grows we will continue to add to our beginning theorization of ECTs' pedagogical content knowledge evolution as documented through their inclusion of literacies in their teaching practices.

\section{Findings: Four Narratives of Evolving Pedagogical Content Knowledge}

In this section are narratives of four ECTs, drawn from participants' experiences as described in the 2014 interviews as well as interviews and field notes from observations of these four participants from 2013 when they were preservice teachers. We highlight how each teacher's understanding of literacies evolved and shaped planning and instructional decisions. Each one discussed how deeply their context shaped their practice in their particular teaching assignment. Some also described how their knowledge of literacy strategies continued to allow them to provide opportunities in which students were able to creatively interact with course content, while others struggled to find such opportunities. We look at differences in how participants view infusion of literacies into their teaching between their preservice teacher interviews in 2013 and the first-year teacher interviews in 2014. 


\section{Byron: A New Science Teacher Identifies Metacognitive Benefits of Literacy Strategies}

Byron was a preservice physics and math teacher in his final practicum at a mid-sized high school in a small town in eastern Canada in the spring of 2013. During a classroom observation on April 24, 2013, Byron used a literacy activity he had learned about in the LCA course, having his students make newspaper front pages about universal gravitation in $12^{\text {th }}$-grade physics. He scaffolded the activity well, using clear instructions, relevant models, graphic organizers, and providing a clear rubric for students. He also used alternative texts about relevant current events, engaged in critical thinking with his class, and did a community circle at the beginning of the class, addressing both critical and social aspects of literacy. Byron used writingto-learn strategies (Daniels, Zemelman, \& Steineke, 2007) such as exit slips, "write-arounds" and brainstorming in his ninth grade science class. In a post-observation interview on April 24, 2013, he noted that he found students more creative and motivated when he used these literacy strategies.

Byron noted that knowledge of "literacy [strategies]...really helped me differentiate, widen my scope of instructional techniques..." His goal for himself as a fulltime teacher the following year was to increase the focus on literacy in his lessons: "I'm gonna get more [literacy happening], like when I get out there and be able to set up norms." Byron planned to set up processes/literacy routines in his science classes, so that literacy could be infused in his classroom. He also wanted to have "more reading involved" in his math and science classes, because he liked how students responded with enthusiasm in these classes.

From the upbeat tone of Byron's observation and interview to a more restrained but reflective phone interview on June 10, 2014, some changes were evident. At the end of his first year of teaching in a private school in western Canada for students with learning disabilities, Byron seemed apologetic about the degree to which he felt he had been successful at integrating literacy strategies in his ninth grade math and science classes: "I didn't do a whole lot of literacy...just getting my feet wet" in the first semester. However, he described how he felt more literacy was happening since January 2014. Two examples Byron offered, both from Grade 9 science, showed he was persevering toward his goal of having more literacy strategies integrated into his courses: First, a feasibility report assignment (a RAFT-type activity) in an electricity unit, in which each student wrote a report as if she or he were the engineer, who had to analyze two different forms of energy and report back; and second, an assignment in which students had to create an advertisement as an ad executive for a space resort, in the space unit. Byron described how students had to "tie in everything they had learned about space exploration and how they would make it kind of interesting for one of [them] to go up in space and spend a night up there." Byron's design and inclusion of these assignments reflected his continued desire to invite and motivate students to use their creativity and literacy practices as a means to the learning in his courses.

Byron noted that the learning strategies that were emphasized at his school as important for all students, and in particular students with learning disabilities, were "similar to the literacy strategies that we learned [in our LCA course] last year," in that both "really focus on...figur[ing] out how [students] learn in order to learn." Byron's awareness of how this metacognitive approach was useful for his students indicated he was thinking about why literacy/learning strategies benefit students, especially those he worked with in this first year of his teaching career. It appeared that Byron's PCK was becoming more refined as he moved from 
seeing literacy strategies as motivating and as inviting creative response to understanding the long-term advantages of a metacognitive approach for students.

\section{Elizabeth: A Physical Education Teacher Juggling Many Responsibilities}

Elizabeth was a preservice teacher with teaching specialties in science and physical education. During her final practicum in a small, rural, middle school, Elizabeth was responsible for teaching multiple Grades (6, 7, and 8) and subject areas (health, physical education, and science). As a preservice teacher, Elizabeth's teaching reflected what she had learned in the LCA course, evidenced in her efforts to create learning activities designed to enable students to deepen their understanding of content. For example, in an interview following an April $29^{\text {th }}, 2013$ classroom observation, Elizabeth described having students in Grade 6 science create vocabulary squares to learn concepts important to the unit on space. Elizabeth also scaffolded an activity in health in which students created a brochure about healthy living, and found ways to include literacy in the teaching of physical education (PE) through the use of daily exit slips. Elizabeth explained that her knowledge of literacy strategies enabled her to be innovative in her planning and assessment in that "writing-to-learn strategies were really good openers and sometimes really good closers in a lesson...I saw them fit in well in terms of introducing something new or wrapping up something students might not." Elizabeth emphasized that even in PE she was able to use the writing-to-learn strategies to help her gain "baseline ideas of ...students' understandings of the physical skills." She says,

"I also found that it was really helpful in getting information on the valuing and knowing outcomes...I did a unit on cooperation...students complete[d] an exit slip on...how they felt they added to group work or how they felt they were a team player and what not...that allowed me to target [inaudible] outcomes and feelings.

Elizabeth explained a shift in her thinking about literacy from taking the content-area literacy course: "I think my coming around to see that all writing doesn't need to be formal writing or public writing for it to have a purpose and to be effective in making better readers and making better writers." Elizabeth seemed hopeful about her first year of teaching and anticipated making use of literacy strategies in her teaching.

In Elizabeth's first year of teaching, there seemed to be a shift in her thinking about the use of literacy strategies. Prior to the follow-up interview during her first year of teaching, Elizabeth emailed to say "I hope that I will have something useful to share with you...I'm finding it hard to do all of the things I'd like to do in class" (Personal correspondence, March 4, 2014). In a phone interview on March 12, 2014, during the final semester of her first year of teaching at a junior high school in a growing community in western Canada, Elizabeth was contrite about her efforts to infuse literacy strategies into her teaching and throughout the conversation attributed this to her busy schedule. Elizabeth explained that she was mainly responsible for teaching several sections of PE for girls in Grades 7-10 in addition to one section of boy's PE and character education class to a Grade 7 class. As part of her responsibilities, Elizabeth was heavily involved in extra-curricular activities at the school, coordinating student council; coaching basketball, volleyball, and badminton; and helping out with the production of the school play.

Because of her multiple responsibilities and the newness of her school and timetable, Elizabeth explained that in her first year of teaching she "was really trying to keep [her] head 
above water and just meet the curriculum outcomes for the specific subject." She emphasized, "if I'm being totally honest... I have felt so overwhelmed...so far that I haven't really felt like I've had the time to really give a lot of the [literacy] strategies a chance in my teaching." In addition to her busy timetable, Elizabeth also identified the school's approach to assessment as an issue; she struggled "with the idea of the way the assessment is run." Elizabeth was cautiously optimistic about her second year of teaching, saying, "Hopefully things will feel a little bit less overwhelming, and less new and daunting, because it won't be the first time." At this stage of Elizabeth's PCK development, it was challenging to name discrete aspects of development, particularly as she was attempting to juggle multiple responsibilities.

\section{Sandra: A Physical Education and Social Studies Teacher's Increasing Confidence}

Sandra taught PE to Grades $7-12$ in a small K-12 rural school during her final practicum. Sandra appeared keen to integrate literacy strategies in PE, a subject in which this might seem more challenging. In a classroom observation in her Grade 12 PE class on April 9, 2013, Sandra introduced a new unit on outdoor pursuits using sketching, exit slip and brainstorming, which are writing-to-learn activities from the LCA course she had taken in the winter term. Her brainstorming activity involved small groups collaborating to address this scenario: "Imagine we are going on a trip to Gros Morne National Park for 3 days. Your group has to consider and write down things you need to think about under your topic for this trip." In a follow-up interview after class, Sandra said she "was really interested in the critical thinking [she] observed during this activity, as students came up with ideas and discussed and refined them." Critical thinking was a focus of the content-area literacy course, and it seemed Sandra showed awareness of how this aspect of literacy could benefit her PE students.

Sandra was hired to teach Grades 7 and 8 social studies, as well as Grades 7, 8, and 9 outdoor education and Grade $7 \mathrm{PE}$ in a middle school in western Canada immediately after completing her BEd, for the months of May and June, 2013. In a phone interview on July 31, 2013, Sandra talked about how she used literacy strategies in these courses. Although Sandra did give examples of her use of exit slips and brochure making in PE and outdoor education, she noted her use of literacy strategies mostly in social studies, which she attributed to the time of year: "Just because the nature of phys. ed and outdoor ed, like at that specific period seasonal time, I guess we were outside." Sandra had social studies students complete multi-genre projects in a unit on Japan and faux Facebook pages of key figures in a unit on the history of the Spanish contact with the Aztecs. Sandra found the success of these projects hinged on the time allotted: She said,

I, like, in getting to know your students, they were a group of students that needed a lot of time and a lot of extra help and so I mean I ... offered at lunch time and afterschool and a lot of them, more than I had estimated, actually used it.

Related to the importance of getting to know her students well, Sandra found assessment advantages in assigning these projects: "I used th[em] more so to measure and gauge what students were understanding and what I need[ed] to spend more time on and so yeah, it was really helpful." Sandra's analysis of why she employed literacy strategies in her classes in those first two months of teaching focused on student engagement. She said, "I think it's a combination of my knowledge of literacy strategies [and] my willingness to not let the kids get bored. Like I always want to keep changing it up every day." 
Toward the end of Sandra's first full year of teaching social studies, outdoor education, and PE at the same middle school where she taught in May and June 2014, she described in a March 10, 2014 interview the importance of her collaboration with the ELA teacher. Sandra said,

So, I teach social studies to Grade 8s, and I've sort of been working alongside their English, or their LA [Language Arts] teacher, just to make sure we're on the same path. I'm trying to teach them the same things that she's teaching, so I guess I'm [re]inforcing what they did.

As part of her attempts to align her teaching practices with the ELA teacher, Sandra used drawing as a tool that students found helpful because, she said, it "seems to simplify [concepts] for them...ah...in a way that they can identify with, so...it also helps as a studying tool." She explained her development of what she called "bell work," a brief activity such as a quote or picture, such as a political cartoon in social studies, to discuss/write/draw about during the 7minute transition between classes in her school. Sandra explained that bell work was "just something to get them [students] thinking and it usually is a quote... as part of an extension of what we're learning."

When asked what goals she might have for use of literacy strategies in her future teaching, Sandra said,

I feel that [writing-to-learn strategies are] a good learning tool for me to facilitate for [students]....Using different writing-to-learn strategies [is important]...because I feel like with that variation, so much more engagement is present, and then the learning takes place at a higher level.

Sandra appeared confident that her use of literacy strategies was benefitting her students, and wanted to integrate them further into her teaching. Her statement that the learning "takes place at a higher level" built upon the comment she made as a preservice teacher and in her July 2013 interview, that engagement of students is of central importance to learning. In this March 2014 interview, Sandra again articulated that engagement leads to deeper learning possibilities and saw the use of learning strategies as fostering these opportunities for students.

\section{Don: Adapting and Responding to Teaching in Northern Canada}

Don thrived in his final practicum at a small rural high school in Nova Scotia in 2013. Responsible for the teaching of music, French, and social studies across several grades, Don noted in an interview on April 29, 2013 that he "had students writing a lot. In the [11th grade] Canadian History class I worked them hard; I was really happy with the outcome." He found literacy strategies "more applicable to social studies," but he also saw ways literacy was part of his music classes.

For music classes we played ... songs with chords, so the students would be, like, following along with the lyrics and looking at the chords that [are] there, you know, above the words to know when to switch. So, I guess that's a type of musical literacy.

Don stated he believed literacy should be infused across all subject areas. He used a broader definition of literacy, which included musical literacy. Don said a goal for teaching in the next year is 
to develop my own literacy skills in music and I would love to have students learn the language of music so they can write for themselves in musical notation, rhythmic notation, learn the variety of different musical notations that are out there and alternate notations; so, definitely I would love to have that be a huge part of my music teaching.

Moving to a teaching position in small, fly-in, Indigenous community in northern Canada where he was responsible for the teaching of Grade 7 English, social studies, and science, Don experienced tensions as he adapted to this new context. A Skype interview with Don on March 9, 2014 revealed he was having a challenging first year of teaching. A number of students in his seventh grade class had been diagnosed with learning disabilities, struggled with reading comprehension, and he felt they appeared disengaged from school. Don said, "I'm really trying hard with the literacy though, especially after Christmas." He taught reading strategies and had students use graphic organizers and other writing-to-learn ideas from the LCA course. After school, Don began a band program and coached hockey. He said, "It's nice to see the students outside of school." Don described larger social issues that affected his community, and was clear that these matters had a significant impact on his teaching:

The school is like the focal point of the discussion between maintaining the cultural identity and heritage [and] accepting the colonization from the South, accepting a southern style of education.... [The school] is symbolic of a battleground, I guess, for you know...fighting against colonization and maintaining your cultural identity.

Don modified his literacy goals in his first year of teaching, as he learned more about the history and context of the community in which he lived and taught, and strove to make his course content and approaches more equitable and relevant for his students. He spoke at length of trying to find "a middle ground" between "try[ing] not to discourage" students who were below grade level in his English courses and fulfilling the duties his school board required of him in terms of assessing student achievement. His thoughtful analysis of his first year of teaching revealed a number of difficult contextual factors. Don remained positive, however: "I'm really hoping that as other things become more settled; then I can better focus on these other areas and hopefully help these kids learn to read and right better." It seemed that Don's goal of making musical literacy a part of his teaching shaped his experiences in this first year of teaching, as he developed an after-school band program to engage students for whom school represented lessthan-positive learning experiences.

\section{Discussion: The Significance of Discipline, Context, and Teacher Education Courses}

This section describes the different ways subject areas/disciplines, school context, and the LCA course seemed to affect the journey from preservice teacher to first-year teacher for our participants, in terms of their integration of literacy into their teaching, and considering their developing PCK (Shulman, 1986).

\section{Does Discipline Matter?}

We analyzed the transcripts for this inquiry wondering, among other things, whether the disciplines of the ECTs played some role in their infusion of literacy practices in their teaching. We review the findings here to address this wonder. Byron, competently engaging students in critical discussion of current events and creating newspaper front pages in a 12th-grade physics 
class as a preservice teacher, found it harder to maintain this momentum in a ninth-grade science class, but gradually began to include activities such as a RAFT and the development of an ad for space travel in his course. For Byron as a science teacher, literacy strategies provided both a creative way to teach content and a means of having students think at the metacognitive level about their learning (Kane, 2011; Rowsell et al., 2008). Evidence of Bryon's developing PCK (Shulman, 1986) could be seen in his gradually increasing facility with choosing appropriate literacy strategies to support his students' learning of science concepts.

Elizabeth and Sandra both taught PE. The observations and interviews with them during their final term as preservice teachers provided evidence of how they included diverse literacy strategies in their teaching. Elizabeth in particular noted the relevance of literacy practices to assessment of her students' understanding of concepts and skills. In her first year of teaching, Elizabeth, with a PE teaching assignment and with heavy extra-curricular demands as a coach, found little space to infuse literacy into her teaching. It is notable that both Elizabeth and Sandra found it more challenging to incorporate literacy in PE courses. Perhaps this speaks to the need to include more PE specific strategies in the LCA course.

Sandra taught social studies as well as PE, and was able to collaborate with the ELA teacher to include critical and visual literacies in her classes. She also found some opportunities to infuse some literacy into PE. From her interviews, it appeared that Sandra's evolving PCK (Shulman, 1986) afforded her an ability to articulate why the shorter strategies she often chose were effective choices in helping her students learn.

Don taught seventh-grade English, social studies and science, and ran an after-school band program. He left his teacher education program with plans to integrate literacy, particularly writing, across his teaching. Don re-thought his goals somewhat in his new context, but he held on to the possibilities of music and musical literacy as a learning path for his students, and learned to incorporate relevant local material into his teaching, with the longer-term intention of integrating reading and writing more successfully in his classroom. Don's stories of his experience in his first year of teaching suggested that although his teaching areas of social studies and ELA might seem easily suited to integrating literacy strategies, this was not necessarily the case. Don indicated in his interview near the end of his first year of teaching that he was aware of the need to continue to develop his teaching strategies in relation to the particular students he taught. We note this as an awareness of his developing PCK (Shulman, 1986).

Overall, there may be some differences among the experiences of these ECTs related to the disciplines in which they taught, but more evidence is needed (Wood et al., 2012). We are not yet certain whether discipline will merit inclusion as a factor in the development of ECTs' ability to infuse literacy practices in their content area teaching or not. As we return to talk with each of them in their second and third years of teaching, our understanding of the impact of this factor will develop further.

\section{Context Definitely Matters}

The significance of context in shaping early career teachers' PCK and their teaching practices around inclusion of literacies is apparent (Day et al., 2007, 2009; Flores \& Day 2006). The schools in which teachers found themselves played a significant role. Byron's more sophisticated conception of how literacy practices can invite a metacognitive awareness of one's 
learning appeared to arise from the particular context of his first year of teaching, in a school with a specific focus on metacognition. Elizabeth's sense of feeling overwhelmed is common among new teachers (Thomas \& Beauchamp, 2011), but it seemed her particular context and its expectations contributed to her inability to find opportunities to incorporate literacy practices into her teaching. Sandra spoke of working closely with the ELA teacher in her school around literacy infusion in her social studies class, indicating the importance of collaboration in her context (Patrick et al., 2010). Don described how his experiences in a school in a northern fly-in community affected his practice and his beliefs regarding literacy in his seventh grade classroom. Despite the challenges Elizabeth, Sandra, Byron, and Don faced in their first year of teaching, each one remained optimistic that they would continue to include literacy in their teaching in their disciplines, and noted ways they had done so already. We continue to focus upon contextual factors shaping early career teachers' inclusion of literacies moving forward into the next year of the study.

\section{Lingering Learnings From the Literacy in the Content Areas Course}

We wondered whether these ECTs' decisions around incorporating literacy into their teaching practices were shaped by taking the LCA course in the final term of their BEd program. All four continued to use some of the language of the course, referring often to such terms as writing to learn, and public (larger) writing projects (Daniels et al., 2007). Byron in particular brought forward the concept of metacognitive strategies from the course and connected it to his teaching in a school that emphasized this. Sandra spoke of often using the folder she (and each preservice teacher) made of various literacy strategies in the course. This folder was a culminating activity designed to consolidate the learning around the variety of strategies addressed in the course. Elizabeth made connections between literacy and assessment, which seemed to relate to the course since one of its features is an emphasis on how literacy strategies can provide important lenses through which to assess students' learning of content (MittonKukner \& Murray-Orr, 2014). Don's expanded understanding of literacy, encompassing musical literacy and more local and relevant course materials, seemed to be influenced by the course, since seeing conceptions of multiple literacies and multimodalities are ideas with which we strive to infuse the course (Mitton-Kukner \& Murray-Orr, 2015). Don's recognition of the importance of teaching with a goal of equity in the forefront reflects the critical literacy focus of the course (Murray-Orr, Mitton-Kukner \& Timmons, 2014).

In summary, we saw a number of ways in which the course appeared to affect how these ECTs perceived the role of literacies in their teaching practice. One of the main goals of our study continues to be the improvement of the LCA course and our focus on literacies as a central facet of our teacher education program. The next years of our study will enable us to make changes based on what ECTs tell us as they reflect on their teaching.

\section{Conclusion}

While we looked at discipline and context separately in the Discussion section, we note the importance of the interplay between the two in the narratives of each ECT. Elizabeth taught PE in a school where the context required her to take on multiple extra-curricular coaching commitments and the PE department did not share her interest in using literacy strategies as a way to teach or assess student learning. There appeared to be an intersection of discipline and context at work to cause Elizabeth to struggle in her attempts to include literacy in her first year 
of teaching. A different example of interplay of discipline and context can be seen in Don's narrative, where his goal to have students become more musically literate coincided with his need to develop relationships with the young people in his school, and to begin an after-school music program.

This paper provides glimpses into the ways in which four ECTs have begun to embed literacies into their teaching practices in content areas, and how their approaches shifted between their final term of the BEd in 2013 and their first year of teaching in 2014. Such glimpses are significant in guiding our work as teacher educators, and we hope they may suggest ways for other teacher educators to support their BEd students.

This study offers promise for us to improve our LCA course. For example, we hope to develop case studies based on this research that can be analyzed by our students to help them begin to anticipate their actions in their first years of teaching, to gain some awareness of the challenges and the possibilities they may encounter. With a growing number of participants in our ongoing study, the next few years should enable the development of a rich collection of cases that will inform both our own teaching and the study of disciplinary literacy practices of ECTs more broadly.

\footnotetext{
${ }^{1}$ In our context, the Bachelor of Education degree is a two-year postgraduate program of study.
} 


\section{References}

Alger, C. L. (2009). Content area reading strategy knowledge transfer from preservice to firstyear teaching. Journal of Adolescent \& Adult Literacy, 53(1), 60-69.

Begoray, D. (2002). "Not just reading anymore: Literacy, community and the pre-service teacher." English Quarterly, 34(3-4), 39-45.

Begoray, D. (2008). There is definitely literacy in music: Meeting the needs of band/choral teachers in a content area reading course. Journal of Reading Education, 33(3), 9-13.

Brozo, W. G., Moorman, G., Meyer, C., \& Stewart, T. (2013). Content area reading and disciplinary literacy: A case for the radical center. Journal of Adolescent and Adult Literacy, 56(5), 353-357.

Cochran-Smith, M., McQuillan, P., Mitchell, K., Terrell, D.G., Barnatt, J., D'Souza, L., \& Gleeson, A. (2012). A longitudinal study of teaching practice and early career decisions: A cautionary tale. American Educational Research Journal, 49(5), 844-880. doi: $10.3102 / 0002831211431006$

Creswell, J. W. (2007). Qualitative inquiry and research design: Choosing among five approaches ( $2^{\text {nd }}$ ed.). Los Angeles, CA: Sage.

Daniels, H., Zemelman, S., \& Steineke, N. (2007). Content-area writing: Every teacher's guide. Portsmouth, NH: Heinemann.

Darling-Hammond, L. (2006). Powerful teacher education: Lessons from exemplary programs. San Francisco, CA: John Wiley and Sons.

Day, C., Sammons, P., Qing, G., Kington, A., \& Stobart, G. (2007). Teachers matter: Connecting work, lives and effectiveness. Berkshire, UK: Open University Press.

Day, C., Sammons, P., Qing, G., Kington, A., \& Stobart, G. (2009). Committed for life? Variations in teachers' work, lives and effectiveness. In M. Bayer, U. Brinkkjaer, H. Plauborg, \& S. Rolls (Eds.), Teachers’ career trajectories and work lives (pp. 49-70). Dordrecht, NL: Springer.

Dunkerly-Bean, J., \& Bean, T.J. (2016). Missing the savoir for the connaissance: Disciplinary and content area literacy as regimes of truth. Journal of Literacy Research, 48(4), 448-475. doi: $10.1177 / 1086296$ X16674988

Flores, M. A., \& Day, C. (2006). Contexts which shape and reshape new teachers' identities: A multi-perspective study. Teaching and Teacher Education, 22(2), 219-232. doi:10.1016/j.tate.2005.09.002

Fuller, F., \& Brown, O. (1975). Becoming a teacher. In K. Ryan (Ed.), Teacher education (74 ${ }^{\text {th }}$ yearbook of the National Society for the Study of Education, Part 2), (pp. 25-52). Chicago, IL: University of Chicago Press.

Hynd-Shanahan, C. (2013). What does it take? The challenge of disciplinary literacy. Journal of Adolescent and Adult Literacy, 57(2), 93-98. doi: 10.1002/JAAL.226 
Issacs, M. L., Elliot, E. M., McConney, A., Wachholz, P., Greene, P., \& Greene, M. (2007). Evaluating "quality" methods of filling the "teacher gap": Results of a pilot study with early career teachers. Journal of the National Association for Alternative Certification, 2(2), 5-22. Retrieved from http://www.jnaac.com/index.php/JNAAC/article/view/49

Kane, S. (2011). Literacy and learning in the content areas. Scottsdale, AZ: Holcomb Hathaway.

Kemmis, S., Heikkinen, H.L.T, Fransson, G., Aspfors, J., \& Edward-Groves, C. (2014). Mentoring of new teachers as a contested practice: Supervision, support and collaborative self-development. Teaching and Teacher Education, 43, 154-164. https://doi.org/10.1016/j.tate.2014.07.001

Lortie, D. C. (1975). Schoolteacher: A sociological study. Chicago, IL: University of Chicago Press.

Mansfield, C., Beltman, S., \& Price, A. (2014). 'I'm coming back again!' The resilience process of early career teachers. Teachers and Teaching: Theory and Practice, 20(5), 547-567. doi: 10.1080/13540602.2014.937958

Merriam, S. B. (2009). Qualitative research: A guide to design and implementation. San Francisco, CA: Jossey-Bass.

Mitton Kukner, J., \& Murray Orr, A. (2014). Making the invisible of learning visible: Pre-service teachers identify connections between the use of literacy strategies and their content area assessment practices. Alberta Journal of Educational Research, 60(2), 403-419.

Mitton Kukner, J., \& Murray Orr, A. (2015). Inquiring into pre-service content area teachers' development of literacy practices and pedagogical content knowledge. Australian Journal of Teacher Education, 40(5).

Murray Orr, A., \& Mitton Kukner, J. (2015). Fostering a creativity mindset in content area teachers through their use of literacy strategies. Thinking Skills and Creativity, 16, 69-79. doi: $10.1016 /$ j.tsc.2015.02.003

Murray Orr, A., Mitton Kukner, J., \& Timmons, D.J. (2014). Fostering literacy practices in secondary science and mathematics courses: Pre-service teachers' pedagogical content knowledge. Language and Literacy, 16(1), 91-110.

Patrick, F., Elliot, D., Hulme, M., \& McPhee, A. (2010). The importance of collegiality and reciprocal learning in the professional development stage of beginning teachers. Journal of Education for Teaching, 36(3), 277-289. doi: 10.1080/02607476.2010.497373

Rowsell, J., Kosnik, C., \& Beck, C. (2008). Fostering multiliteracies pedagogy through preservice teacher education, Teaching Education, 19(2), 109-122.

Shulman, L. S. (1986). Those who understand: Knowledge growth in teaching. Educational Researcher, 15(2). 4-14. doi: 10.3102/0013189X015002004

Street, B. (2014). Social literacies: Critical approaches to literacy in development, ethnography and education. Toronto, ON: Routledge. 
Thomas, L., \& Beauchamp, C. (2011). Understanding new teachers' professional identities through metaphor. Teaching and Teacher Education, 27, 762-769. doi: 10.1016/j.tate.2010.12.007

United Nations Educational, Scientific and Cultural Organization (UNESCO). (2008). A review of concepts, methodology and current data. Montreal, PQ: UNESCO Institute for Statistics.

Wood, M.B., Jilk, L.M., \& Paine, L.W. (2012). Moving beyond sinking or swimming: Reconceptualizing the needs of beginning mathematics teachers. Teachers College Record, 114(8), 1-44.

Yin, R. K. (2014). Case study research: Design and methods. Los Angeles, CA: Sage. 